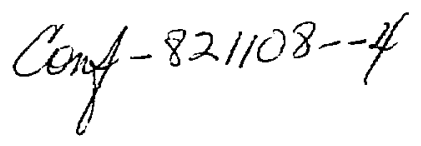

Submltted to 1982 Applied Superconductivity Conference, Knorville, TN, liov. 30 to Dec. 3, 1982 .

BNL 31396 .

BNL- -31396

DE83 000717

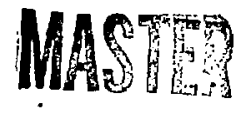

CORRELATION OF SUPERCONDUCTOR STRAND, CABLE, AND DIPOLE CRITICAL CURRENTS IN ISABELLE MAGNETS, M.J. Tannenbaum, M. Garber, H.B. Sampeör, Brookhaven Nat lonal Laboratory - A callbration between vendor eritical current data for $0.0268^{*}$ diameter superconductor strand supplied to Permilab, and the BNL $10^{-12}$ Qum eritical currenc spevificacion is presented. Vendor critcal current data for over 400 Berallab type bi1lets are shown, both os supplied by the Vendor and converted to BNL units. Predictions of cable critical current are ande using the sum of the critlcal currents of the 23 strands, where all atrands from the same half billet are asignad the same critical current. The meabured cable critical current shows excellent correlation to the predicted value and is approximately $14 \pm 2$ percent below 14 . ISABELLE full length dipoles reach the conductor critical current limit, easentially whout training. Magnet performance is predictable from the meagured critfcal current of short sample of cable to within $2 \%$.

*

Work performed under the ausplees of the U.S. Dapartaert of Energy.

MDTIRE

PORT!OHS OF THS REPQRT ARE ILEGIBLE.

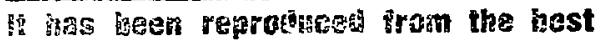
avillable CBay to pernit the broadest puss 5 iste ayaisasility.

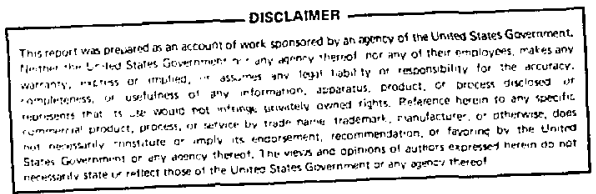




\title{
CORRELATION OF SUPERCONDUCTOR STRAND, CABLE, AND DIPOLE CRITICAL CURRENTS IN ISABELLE MAGNETS
}

\author{
M.J. Tannenbaum, M. Garber, and W.B. Sampson
}

\section{Ferwilab Experience Compared to BML Expectaclons}

An outline of the steps lnvolved in cable production from billet to strand to cable is shown in F1gures $O A$ and $B$.

Ferm1lab has provided us with the manufacturer.'s current certifications at 5.0 Tesia $4.2^{\circ} \mathrm{K}$ for a representative strand from each half billet for 120 half blllets labelled 163-1 through 222-2 f5on MCA and 282 billets numbered 02 through 348 from IGC. Also, as part of thefr proposal to us IGC submitted data to us on 82 strands from 41 blllets numbered in the range 301 to 350 .

All thls data has been entered into the data base. For MCA, separate entrles are retalned for each half blllet, but for ICC the two samples per

$\therefore$ billet are averaged. A histogram of all the data is shown in Figure 1. The data are tabulated in Figures 2 and 3 . The means and standard deviations of the distributions are nearly 1dentical but the MCA distribution 1 s nore sker, heving a longer tall at low currents. Based on this 1niornation, a requirerent of a 240 ampere mininum for the material seemed eminently reasonable since only $4.2 \%$ of the MCA conductor and $1.4 \%$ of the IGC was below this value.

According to the Fermilab strand Spec. 1610-ES-54654 and engireering note EN-740904-1 (wr15ten by none other than B. Strauss, now of MCA) the short sample critical current is deffined at an effective resistivity of $10^{-12}$ scm. If the sazple quenches at a lower effective resistivisy, then the quench curzent is used. Through the cooperation of Bob Remsbotton and A1 McInturfe of FNAI, and Bruce Zetelin and Kanith1 Hemachalam of IGC, a cross comparison was made between $\mathrm{BNL}$ 's measurement of $10^{-12} \mathrm{Qcm}$ critical current as specffied by Meyer Garber and B1II Sampson In IN 349 and the dara given by the strand manufacturers to Ferdilab. Seven wire samples were provided to us by IGC. MCA wire samples were provided by Fermllab as part of our cable procurement. F1gure 4 shows a conparison between the same sample reasured at IGC, BNL and FNAI. Agreement between BNL and IGC 1s excallent. Four of the FNAL measurements agree but two are h1gh by $\sim 10 \%$.

At the time when these measurements were performed, a comparlson betveen our own weasurements and those sent by IGC to Fermilab revealed that the numbers in ICC's strand certification to FNAL were about $12 \%$ higher than the $10^{-12} \mathrm{gcm}$ neasurements. In a telephone check to IGC, they freely admitted that their certiflcation to Fermilab was at an effective resistivity of $1.3 \times 10^{-11} \mathrm{Rct}$, which explains the difference. They subsequently put this information in their wricten proposal to us (frod which Figure 4 is taken) and sugzested that we change the minimum current specification accordingly if we wanted to use our $10^{-12}$ Rcm critical current definition. The reason for thelr request becones clear if we norialize the1r billet data to our $1 \times 10^{-12}$ Qcm definition by aultiplying by a factor of 0.892 as datermined from Figure 4 . The conversion factor for MCA is 0.875 as deteralned from the daca in Figure 5 . 
The average conversion factors are used for all billets. For both manufacturers the actual conversion factor on a blllet varles from the average with a $\sim 3 \%$ Ris spread.

The manufacturer's billet data converted to the BNL curcent definition are shown in Figure 6 and tabulated in Figures 7 \& 8. The data for both manufacturers are now nearly 1ndistingulshable. They can be characterizel by a mean current of 244 anperes, with a standard deviation of 16 amperes (or 6.57) about the mean. While it is pleasing to see such consistency among the manufacturers, the distressing part is that $40 \%$ of the conductor would fall the 240 ampere minimum current according to our definition. Instructions from Bob Palmer were to specify Fermilab's actual waterlal, so ISABELLE Spec. 89 was revised (Rev. A, March 3, 1982) to requie 220 anperes minimun current and a length welghed average current over four billets of at least 240 amperes. This was meant to reflect the data of Figure 6 . For both manufacturers, about 57 of the billets in Figure 6 fall below 220 anperes and would be rejected.

A more comon misthod of displayling manufacturer's yleld eurves is to use probab1lity paper. The critlcal currents corresponding to the percentiles of the Integrated distribution are plotted. The trick of probability paper is that the probability scale is linear in standard devlations (for a Gausian) so that a pure Gaussian distribution will be a stralght ilne. As shown in Figure 10, the ICC distzibution is Gaussian from the 5 to 98 parcentile while the MCA has a tall at low currents and 13 truncated at higher currents.

Another quest1od to ask with this data is whether there was improvement or consistency over the production. The manufacturer's blllet data in BNL units are plotted 1 in Figures 11 and 12 against billet nunter. The IGC data (F1g. 11) shows all the unacceptable blilets at the beginning of production and then reasonable consistency over 300 billet nusbers. Unfortunately, the MCA data (FIg. 12) show poorer billets in the latter part of thelr production. He shall soon be in a position to evaluate this information with our own strand. However, it has been enlightening to be able to analyze, as a warmup, data frcu Ferm1lab on superconductor correspond1ng to 425 full length ISABELLE dipoles.

As a closing remark to this section, we can hazard a very educated guess on the discrepancy in short sample currents between Fermilab and BNL. BNL defines the critical current at an effective resistivity of $1.0 \times 10^{-12} \mathrm{Rcm}$ over the full strand dlaneter whth the full gauge length of $50 \mathrm{~cm}$ subjected to a perpendicular conponent of magnetic fleld within $1 / 2 \%$ of the 5.0 Tesla specifled value. In the Fermilab sampie nolder used for borin srrand and cable, the saaple is held in a $3^{n}$ diameter sent-circle in the plene of the magnetic fleld of the solenold. Thus only 6 to $9 \%$ of the sample 15 subjected to a perpendicular conponent of magnetic field within $1 / 2$ to $1 \%$ of the specified value. If the effective resistivity is calculated using the full sent-circular length of conductor between thr voltage taps, an error of a

- factor of 11 to 16 in effective resistivity results. This is consistent with IGC's statement that the effective resistivity in the Fitd sample holder is $1.3 \times 10^{-11}$ Qcid rather than $10^{-12}$. 
II. Comparison of BRL. Cable Short Sample Measurement With Billet Data And Cable Maps Supplied By Outside Vendors

For each cable supplied by NEEHC, a map of the strands is provided as shown 1n Figure 13. Thus the start of COO25IN consises of 20 strands of S-347 and 3 strands of 5-328 while the end of co020IN (and thus the start of C0021IN) consists of only 4 strands of s-347 and 19 strands of S-328. Kolduelds, made when spools of strand are changed, are Indicated by an $x$. These maps have been entered lato the data base. In addition, the billet critical currents provided by the manufacturer (Fig. 14) have also been entered. Penny Baggetr has writeen a progran to sum the ranufacturer's billet currents (corrected to BNL units) for the 23 individual superconductor strands for each segrent of cable between Roldwelds. In this way a map of the critical current varlation over the entire cable can be obtalned. This is shown In Figure 15 for a typical cable, COO2lIN, in which the computed critical current varies from 6017 amps at the start of the cable to 6154 amps at the end. From the production polnt of view, the worst cable we have recelved is c0020IN (F1g. 16) whose conputed critical current varies from 5467 amps at the start to 6017 amps at the end. Of course from the RsD point, this is the most interesting cable.

The $10^{\prime}$ short sample of cable whose critfcal current is measured by Meyer Garber 15 altays takan from the start of the reel. The start of a finished insulated reel of cable is the same as the start indicated on Figure 13 becausa the cable is wound on a reel after cabling and then rewound in the course of insulating. I have compared Meyer's measured short sample current to the computed value fror the front end of the cable maps. This is tabulated In Figure 17, and a plot of neasured versus conpured current is shown in F1gure 18. A clear correlation is observed in Figure 18, however it is Dore instructive to study the tabulated data (F1gure 17).

Concentrating on cables co009IN through co024IN (9I thru $24 \mathrm{I}$ in the table), the mean $I_{c 2}$ short sample current is 5039 amps and the varfation about the mean is $4.3 \%$ RMS. The rat1o of the measured short sample $\left(I_{C 2}\right)$ to the computed short sample current averages 0.866 w1th a variation of $2.6 \%$ RMS. The reduction in variance indicates a correlation between the computed and measured short sample critical currents. (The level of significance of this correlation is left as an exercise for the reader.) The problem is made nore difficult by the high quality of the cables. The ratio of the minimum to naximum critical currents of each cable 1s tabulated (Flgure 17). The average variation over a cable is only 3\%. The largest predicted short sample variation is from the start of cable 20 to the end of cable 20 (whlch is identical to the start of cable 21). The measured data nicely track this. Also, a plot of $I_{\mathrm{C}_{2}} / I_{\text {ss }}$ start on probability paper (F1gure 19) shrws an Impressively good Gaussian distribution in agreement with the fitted paraneters.

W1th the data 1llustraced above, it would appear that we now have the possibility to predict the short sample critical current of each foot of each cable to a precision of $2.6 \%$ RYS. Two questions arfse: Is 1 t worth 1 t? and can we do $1 \mathrm{t}$ any better? For the RSD phase tt is probably worth it because 


\section{...}

the magnets are stable in quench current to a reproductb1lity more 11ke 0.17 RMS. For the production phase, I would expect that the cables could be made cons1derably more reproducible than at present. The manufacturer's billet data in F1gure 6 1ndicate a mean current of 244 amperes and a $6.5 \%$ RMS spread. If we had enough billets to make cable with 23 random samples frou this distribution, I would expect an average cable $I_{c 2}$ of 4860 amperes, with a spread about the average of 1.47 RYS. Of course if we carefully matched strands, we could reduce the spread still further. The present cables have a larger spread because they are made with strand from only 2 to 5 blilets. Also, as shown in Figure 20 for cable 17, Indlvidual cable segments may contaln strand from only a single billet.

There is also plenty of roon for 1nprovenent of the calculated short sample current. The present example used manufacturer's data on critical current for two representative strand short samples for each billet. As shown Ia Elgures 4 and 5 the correlation of our ow measurenents of $1 \times 10^{-12}$ Qcr critical curient to the manufacturer's FNAI definicton strand current was on'y

.. good to $2.7 \%$ RMS, the same preciston as our correlation to the cablest In this Light, the correlation to the predicted cable short sample is really Iupressive and we would expect to do much better when we used our own difectly veasured values for the strand critical current.

The other aspect is how well the two selected strands represent the critical current of the 210,000 feet of strand in a billet. The only direct evidence we presentiy have on this subject cones fron our measurement of the individual strands mak1ng up cable 17. Cable 17 was heav1ly studied because 1t had an 8\% lower short sapple current than the prevlous? cables gede with IGC strand. It was also noteworthy $(\bar{F} 1 \mathrm{~g}$. 20) because all the strand at the start of this cable cane frow billet 332-I. The samples of strand from each spool, routinely supplled to us by NEEWC, were tracked down and measured. The results are shown in Figure 21. The reason for the $A, B . .$. nomenclature is that the manufacturer's spools of up to 30,000 feet of strand are. cut down to spools of length 7000 to 8000 feet by NEEWC. I have averaged the data from the Individual spools. The maximum variation over a spool is $2.0 \%$ RMS. However it is clear that the critlcal current variation over this billet is $6.2 \%$ RYS which is roughly the same as that given in Flgure 6 for IGC's entire b1llet production. It turns. Out that by accident I know that the IGC current certifications for this billet (F18. 14) cone from reels 1 and 7 . Thus the data for this billet are consistent with reels 1 thru 10 ( 131,000 feet) having 250 ampere critical curreat and reels $13-24$ havlng 225 ampere critical

current. I don't think that it pays to do more work on this particular b1llet. However we should make careful measurenents of short sample variations over the length of a billet when we get our own materfal. 


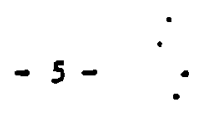

III. Relationshtp Between Cable Short Sample Current And Magnet Perforance Is There Any?

In order to relate the cable short sample measurement at 5.0 Tesla and $4.22^{\circ} \mathrm{K}$ to the magnet performance, one needs to know the varlation of crittcal current with magnetic fleld and temperature, and the magnet transfer function. For LYS \& LY6, the transfer functlon seems to have stabilized (E. Willen, SIIG 94) and I use the parameterization

$$
\tau=\frac{B(I)}{I}=1.3732(1-0.065[I-4.000])
$$

whtch seems to be adequate for 2.5 \& $64.0 \mathrm{kA}$ (My units are TesIa and kiloamperes.)

The critical curreat variation with temperature and tragnetic field is not adequately mapped for the 6 Tesla $3.0^{\circ}$ Kelvin reglne we are work1ng In. The .. best data comes from TN 238, Figure 3, for the old, bralded, conductor (FIg. 22). Hote that this figure also appears in TN 320, Figure 13. I had previously noted (TN 238) that any constant transfer function gives a load Ine short sample current behavior versus temperature which remarkably 1inear and extrapolates to zero at between 9.5 and $9.6^{\circ} \mathrm{K}$. This is shown on Figure 22 for $t=1.50,1.40$, and 1.25. Note that this does not depend on the assurptIon BI - $K(I)$, or any other assumption since it is obtained directly from the measured data. Thus if a magnet is at short sasple at one temperature, 15s behavior at another is predlcted by a stralght line passing through $9.6^{\circ} \mathrm{K}$ for a constant .. However, since our $\tau$ varies, I do the extrasolation using the local :. Also the conductor behavior for fields above 5 Tesla and terperatures below $4.2^{\circ} \mathrm{K}$ is not avallable. Hence I propose that the data of Fig. 22 be remeasured for a typlcal 4900-5000 emp cable at flelds from 0 to $6 \mathrm{I}$ and tenperatures from $10^{\circ} \mathrm{K}$ to as low as possible.

For all the cables measured (F1g. 23) there is typically a $i$ to $2 x$ loss In $B \times I$ at 5.5 I compared to $B \times I$ at 5.0 T. I thus conpute the angnet short sample as follows using $I_{c}$ at $2 \times 10^{-12} \mathrm{ecm} 5.0 \mathrm{I}$ and a peak fleld enhancement of 1.02 .

$$
I_{L L}=\sqrt{\frac{0.98 \times 5.0 \times I_{c_{2}}}{\tau\left(I_{L L}\right) \times 1.02}}
$$

I use the reaker cable of the 1nner coll for the computations. For LM6 this is $14 I, 5.260 \mathrm{kA}$ and for IMS, 18I, $4.749 \mathrm{kA}$. I start with $\tau(4 \mathrm{kA})$ and iterate:

$$
I_{4.2 \mathrm{~K}}=1.8704 \bar{r}_{\mathrm{c}_{2}} \quad I_{4.5^{\circ} \mathrm{K}}=\frac{9.6-4.5}{9.6-4.2} I_{4.2 \mathrm{~K}}^{\circ}
$$




\begin{tabular}{|c|c|c|c|c|c|c|c|c|}
\hline \multirow[b]{2}{*}{$I^{*}{ }_{4.2 \mathrm{~K}}$} & \multirow[t]{2}{*}{ LM6 } & \multirow{2}{*}{$\begin{array}{l}5.260 \\
(k A)\end{array}$} & $\varepsilon_{3}$ & & \multicolumn{3}{|c|}{ L45 $\begin{array}{l}4.740=I_{c_{2}} \\
(\mathrm{kA})\end{array}$} & \\
\hline & & & & & & 4.072 & & \\
\hline$I_{4.2 \pi}$ & & 4.331 & 5.82 & Tesla & & 4.082 & 5.58 & Tesla \\
\hline$I^{\circ}{ }_{4.5 \mathrm{~K}}$ & & 4.067 & & & & 3.860 & & \\
\hline$I_{4.5 R}$ & & 4.076 & 5.57 & Tes 1a & & 3.842 & 5.33 & Tesla \\
\hline
\end{tabular}

The results are plotted in Figure 23 compared to the magnet performance as drawn. by Per Dahl. At $4.5^{\circ} \mathrm{R}$, the prediction for LM5 $151.8 \%$ too low but for LM6 it is right on. It is zewarding that the aagnet with higher current cable performs betcer. However the $1.8 \%$ discrepancy for LMS is lagger than I vould have liked. More data would kelp sort this out. It is also Intersting to note that at $3.8^{\circ} \mathrm{K}$, LMS performance agrees wh h the extrapolation fron $4.5^{\circ} \mathrm{K}$ but IM6 falls below 1t, even after considerable trainfng.

Iv. Conclusion

The cable conductor electrical properties are now understood to a precision of rough $1 \mathrm{y}$ 27 RMS. If we obtaln vendor performance equal to the FNAL history once our own strand plpeline is filled, then it would be possible co obtain cable with an average $I_{c}$ (at $2.0 \times 10^{-12}$ ecm resistivity, 5.0 Tesla and $4.22^{\circ} \mathrm{K}$ ) of 4860 amperes, and a $1.4 \%$ RYS spread about the average. Furtherwore, magnet current limfirion due to superconductor criflcal current should be predictable at the $1 / 2 \pi$ level. 
A 2070 moti noos in copptn tubers wil HE XAGOMAL SWAPE QUIT: SURFACE. DDg DIAHI IL 0.126 IKCHES.
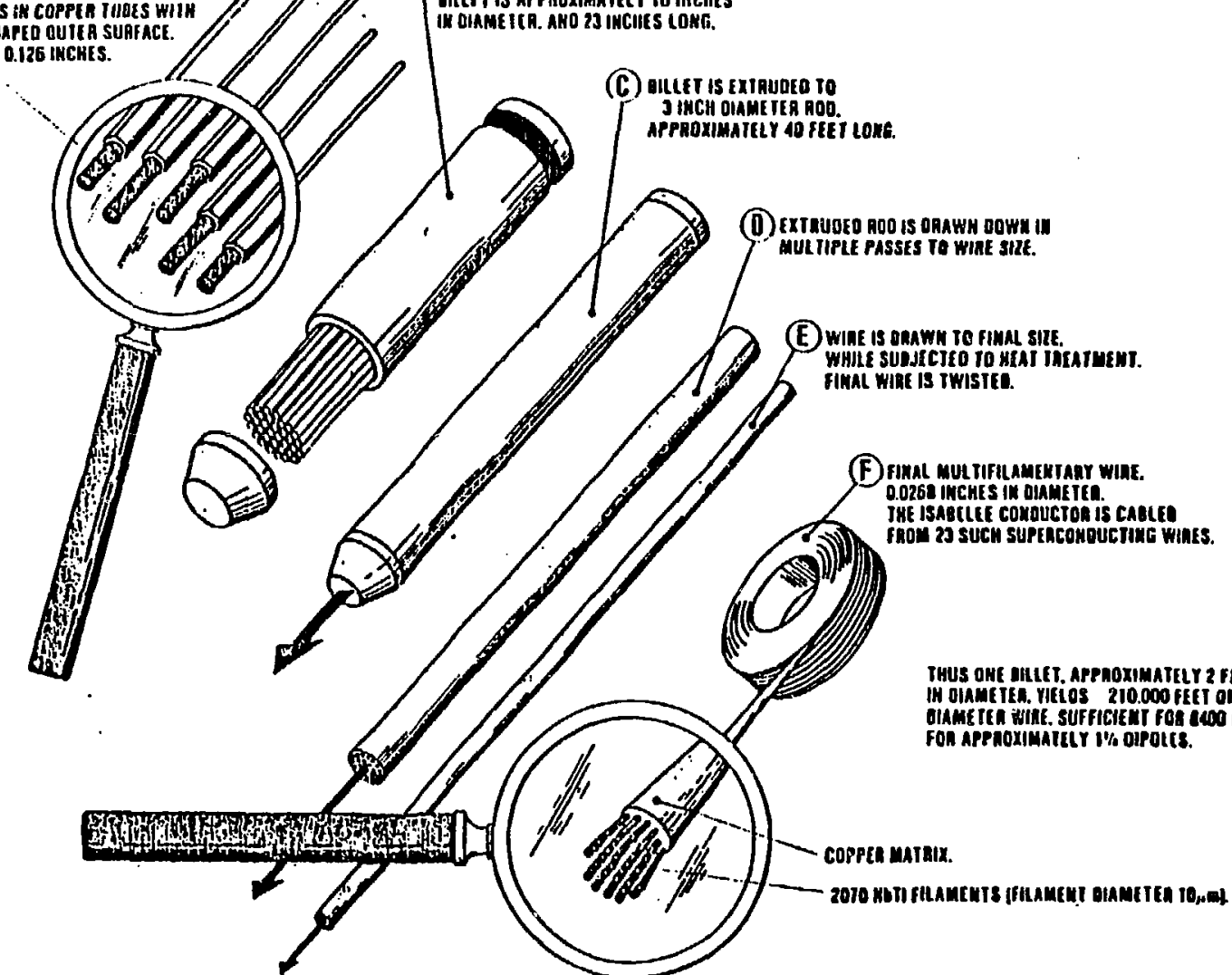

STEPS IN THE PDODUCTION OF

MULTIFILAMENTARY SUPERCOHOUCTIHR WIRE 


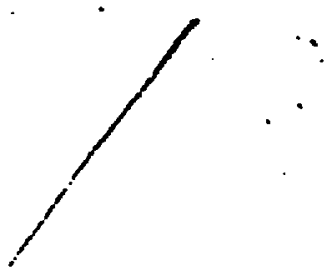

COIL OF MbTi

SUPERCOHOUCTIHE

CABLE

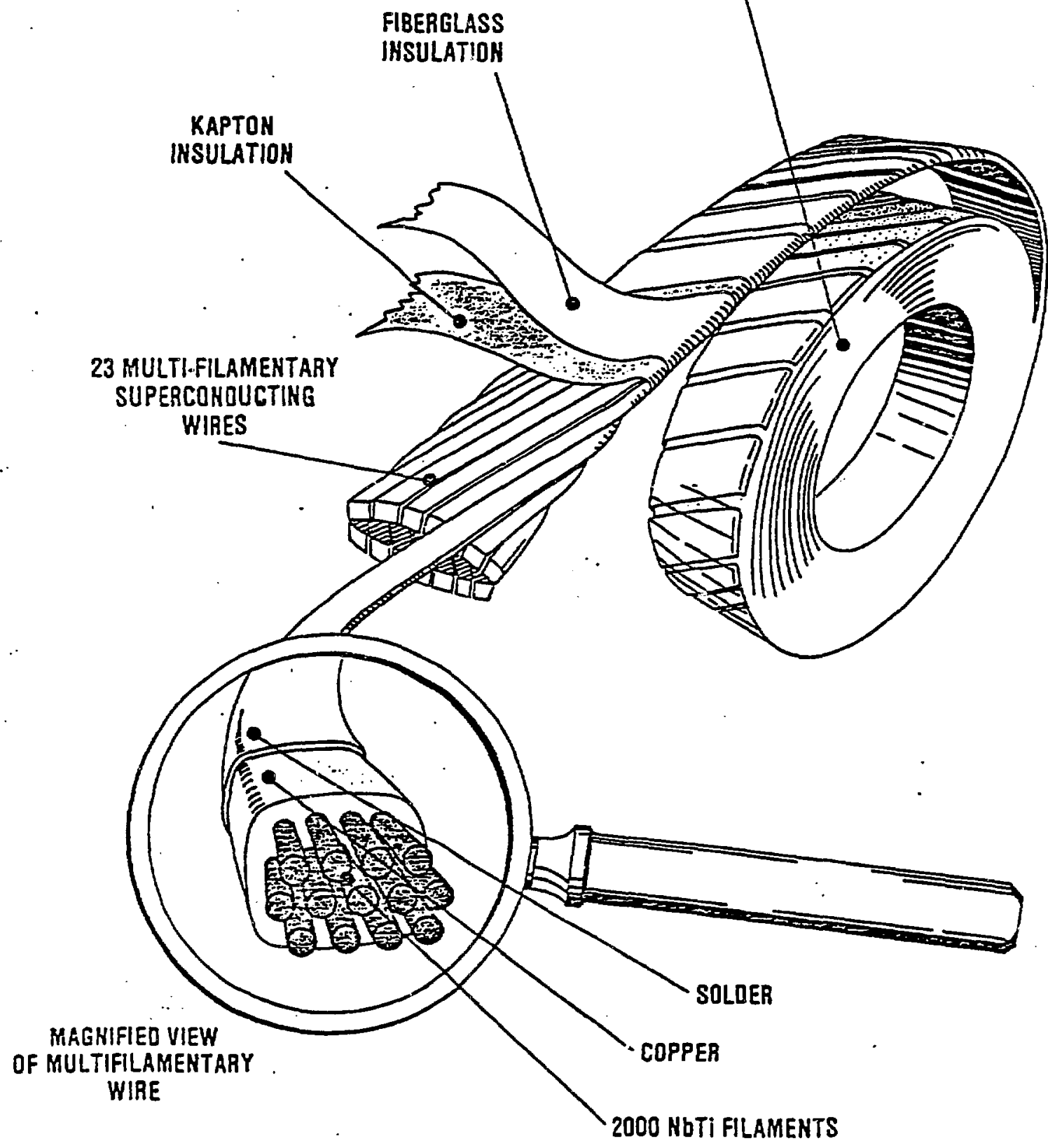


FNAL SPEC-Min,UN CURART

$\because$

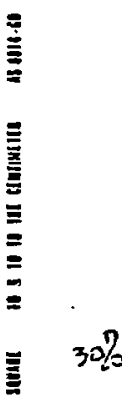

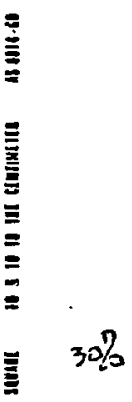

11111

121

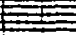

12

120

12 1111211 $1+11211$

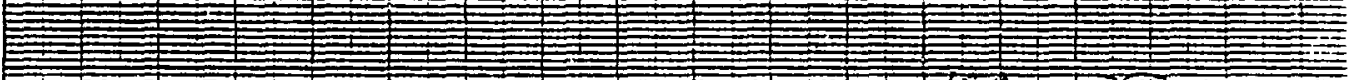

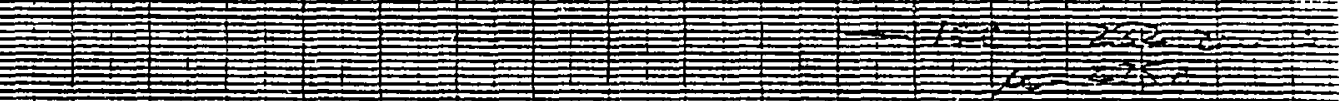
1101011210

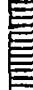

20,3

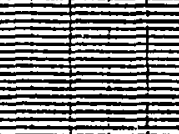

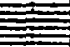


$\therefore$ IITHID-g CRITICNL CURREHT FOR MHF - I

Ii: CI:JTJCNI. CURREHT (ARPS). GY MAHUFACTURER

: iVIIISTILS, ....

\begin{tabular}{|c|c|}
\hline 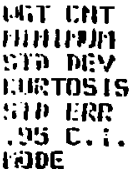 & $\begin{array}{r}202.000 \\
211.000 \\
10.030 \\
0.270 \\
1.074 \\
272.950 \\
275.060\end{array}$ \\
\hline
\end{tabular}

VHL ID OBSERVATIOHS

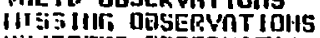

IVIJECHED UESERVATIOMS
202.000

19. 030

0.270

2.950

.060
282

\begin{tabular}{|c|c|}
\hline $\begin{array}{l}\text { MAXITIM } \\
\text { MERH } \\
\text { SKELLHESS. } \\
\text { VAR IAHICE } \\
\text { C.V. PCT } \\
\text { TO } \\
\text { HED IAH }\end{array}$ & $\begin{array}{r}324.8130 \\
275.654 \\
0.059 \\
325.875 \\
6.555 \\
277.159 \\
275.147\end{array}$ \\
\hline
\end{tabular}
$-$

; IR SYSTEM Z.B. 5 ITRAHD'S CRITICIIL CURREHT FOR INF - I

IC

CRITICAL CURRENT (AIPS), BY IAHUFACTURER

\begin{tabular}{|c|c|c|c|c|}
\hline $\begin{array}{l}\text { LuNGer } \\
\text { Lilitit }\end{array}$ & $\begin{array}{l}\text { UPPER } \\
\text { LIMIT }\end{array}$ & $\begin{array}{l}\text { ABSOLUTE } \\
\text { FREOUEMEY }\end{array}$ & $\begin{array}{l}\text { RELATIVE } \\
\text { FREOUEMCY } \\
\text { (PERCEHT) }\end{array}$ & $\begin{array}{l}\text { CUMULATIVE } \\
\text { REL FREG } \\
\text { (PERCEHT) }\end{array}$ \\
\hline \multirow[t]{2}{*}{$\begin{array}{l}210.00 \\
230.00 \\
2310.00 \\
250.00 \\
250.00 \\
270.00 \\
200.00 \\
290.00 \\
300.00 \\
310.00 \\
320.00\end{array}$} & 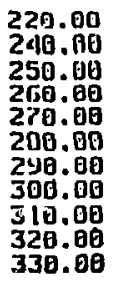 & $\begin{array}{r}2.00 \\
2.00 \\
15.00 \\
34.90 \\
53.00 \\
60.60 \\
52.00 \\
26.80 \\
29.60 \\
7.00 \\
3.60\end{array}$ & $\begin{array}{r}0.71 \\
0.71 \\
5.32 \\
12.06 \\
10.79 \\
29.11 \\
18.44 \\
9.22 \\
7.09 \\
2.48 \\
1.06\end{array}$ & $\begin{array}{r}0.71 \\
1.42 \\
6.74 \\
18.79 \\
37.59 \\
61.78 \\
80.14 \\
09.36 \\
96.45 \\
90.94 \\
100.90\end{array}$ \\
\hline & TOTAL & 202.00 & 100.00 & 180.00 \\
\hline
\end{tabular}


GTIRAMA'S CRITICAL CURREHT FOR MHF - M

II: CRITICNL CURRENT (AIPS), GY IMMUFACTURER

;HATISTICS.....

\begin{tabular}{|c|c|}
\hline 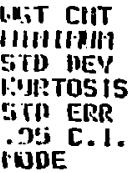 & $\begin{array}{r}120.009 \\
216.256 \\
10.213 \\
1.235 \\
1.663 \\
274.094 \\
275.000\end{array}$ \\
\hline
\end{tabular}

Wil. In DBSERVITIIOHS

IITS IMT DINSTPYATIOHS

H:.ITECTED UUSERVATIOHS
(SIR 2.0.5)

- 01/22/日? 13:3:21:42 PAGE

S I R S Y S T E M $2: 0.5$

MaXIMUI $\quad 312.509$

SKELNESS

VARIAHICE $\quad 331.695$

V.PCT 6.547

291.479
IEDIAH

STRNWD*'S CRITICAL CURREHT FOR IMIF - $M$

IC

CRITICAL CURRENT (AIPS), GY MANUFACTURER -

\begin{tabular}{|c|c|c|c|c|}
\hline $\begin{array}{l}\text { LOLER } \\
\text { LIMIT }\end{array}$ & $\begin{array}{l}\text { UPPER } \\
\text { LIMIT }\end{array}$ & $\begin{array}{l}\text { AGSOLUTE } \\
\text { · FREOUEMCY }\end{array}$ & $\begin{array}{l}\text { RELATIYE } \\
\text { FREQUENCY } \\
\text { (PERCEHT) }\end{array}$ & $\begin{array}{l}\text { CUINLPTIUE } \\
\text { REL EREA } \\
\text { (PERCEIT) }\end{array}$ \\
\hline \multirow[t]{2}{*}{$\begin{array}{l}210.00 \\
220.00 \\
230.00 \\
210.00 \\
250.00 \\
260.00 \\
270.00 \\
200.60 \\
290.00 \\
303.00 \\
310.00\end{array}$} & $\begin{array}{l}220.00 \\
230.00 \\
2010.00 \\
250.00 \\
260.00 \\
270.00 \\
200.00 \\
290.00 \\
390.00 \\
310.00 \\
320.00\end{array}$ & $\begin{array}{r}1.00 \\
2.00 \\
2.00 \\
2.00 \\
6.00 \\
18.06 \\
30.00 \\
27.00 \\
16.00 \\
15.06 \\
1.06\end{array}$ & $\begin{array}{r}0.03 \\
1.67 \\
1.67 \\
1.67 \\
5.00 \\
15.00 \\
25.09 \\
22.50 \\
13.33 \\
12.59 \\
0.03\end{array}$ & $\begin{array}{r}0.03 \\
2.50 \\
4.17 \\
5.03 \\
19.03 \\
25.03 \\
59.03 \\
73.33 \\
95.67 \\
99.17 \\
100.00\end{array}$ \\
\hline & TOTAL & 120.00 & 100.00 & 100 \\
\hline
\end{tabular}


CRITICAI CURRENT DATA

FROM LONG AND SEORT SAMPLE TESTS

CONDUCTED AT BNL, IGC AND FNAI

\begin{tabular}{|c|c|c|c|c|c|c|}
\hline SENS ITIVITY & \multicolumn{3}{|c|}{$2 \times 10^{-12} 8 \mathrm{~cm}$} & \multicolumn{2}{|c|}{$1 \times 10^{-12} \mathrm{ncm}$} & $21.3 \times 10^{-11} \mathrm{ncm}$ \\
\hline PIACE OF TEST & BNL & IGC & ENAI & BNL & IGC & IGC \\
\hline SAMPLE LENGTH & LONG & LONG & SHORI & LONG & IONG & SEORT \\
\hline SAMPIE NO. & & & & & & \\
\hline $327-01$ & 244 & 244 & 260 & 237 & 235 & 275 \\
\hline $327-11$ & 273 & 275 & 275 & 266 & 268 & 302 \\
\hline $329-15$ & 270 & 269 & 275 & 253 & 262 & 290 \\
\hline $335-05$ & 283 & 280 & $28 \mathrm{C}$ & 276 & 272 & 302 \\
\hline $337-29$ & 243 & 244 & 275 & 235 & 234 & 270 \\
\hline $339-13$ & 308 & 298 & 305 & 302 & 292 & 325 \\
\hline
\end{tabular}

$\begin{aligned} & \text { Bff } \frac{\text { BWL }}{F A L} 0.862 \\ & 0.881 \\ & 0.907 \\ & 0.914 \\ & 0.870 \\ & \frac{0.9790 .920}{0.89210 .024}\end{aligned}$


M.C.A

WIRE TEST RESULTS

PALMER CABLE

SAMPLE

$5179-1-M$ BNL 002

$5180-2-1-M$ BNL 003

$5 / 87-1-10-M$ ONA 3

$5192-2-M$ ONL DOZ

$5189-2-5-M$

$5174-1-4 A-M$

$5175-2-17-M$

$5177-1-9-M$

$5176-2-4 A-M$

$5190-1-5 A-M$

$r$

$5174-1-48-M$

$5187-1-8-M$

$5180-2=1 A-M$

S174-1-4C-M

$5179-1-4-M$

S190-2-12-M

$5188-1-11-M$ :

$5173-1-1-M$
$I_{C} I_{Q} \vee_{Q}\left(\frac{(\sin C)}{M C A}\right)\left(\frac{B N}{M-A}\right)$

Ames amps $\mu \nu$

$248 \quad 3103000301.824$

$235 / 295800 \quad 269.874 \ldots$

255. $333 \quad 4500 \quad 281 \quad .904$

252, $309 \quad 1150 \quad 282 \cdot .894$

$240^{\circ} \quad 310 \quad 2700 \quad 278: 863:$
$10-12-81$

E. SPERRY

$\begin{array}{llll}228 & 281 & 1000 \cdot s-640\end{array}$

$245.300,5000 \cdots 274 \cdots .894 \vdots$

$241: 287 \quad 700 \quad 272 \quad .886$

$242 \because 295 \div 1100.276 \ldots 877$

$244 t^{\prime \prime} 290: 1230 \cdot 267: 914$

$226 \% 282 \quad 3800: 265 \quad .853$

$249 \cdot 292 \cdot 750.4606$

$235: 286.4300$ seedere

$\therefore 243: 2973500: 283-859$

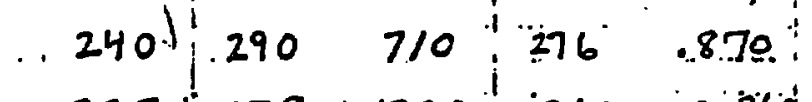

$225: 278 ! 1320 \div 261 \quad 0.862$

.3

0.875

W/RE FROM

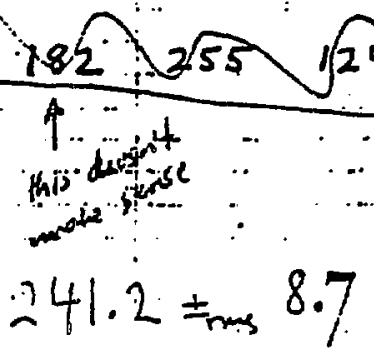

$2,0.024$

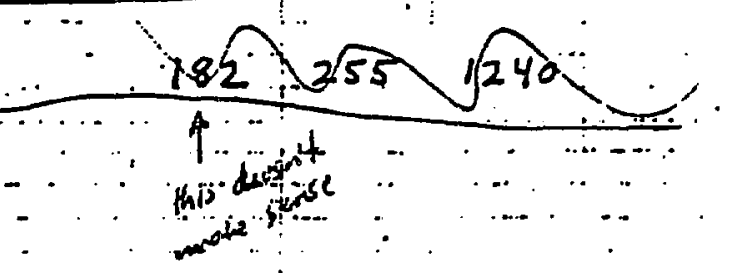

$$
241.2 \pm \text { mes } 8.7
$$




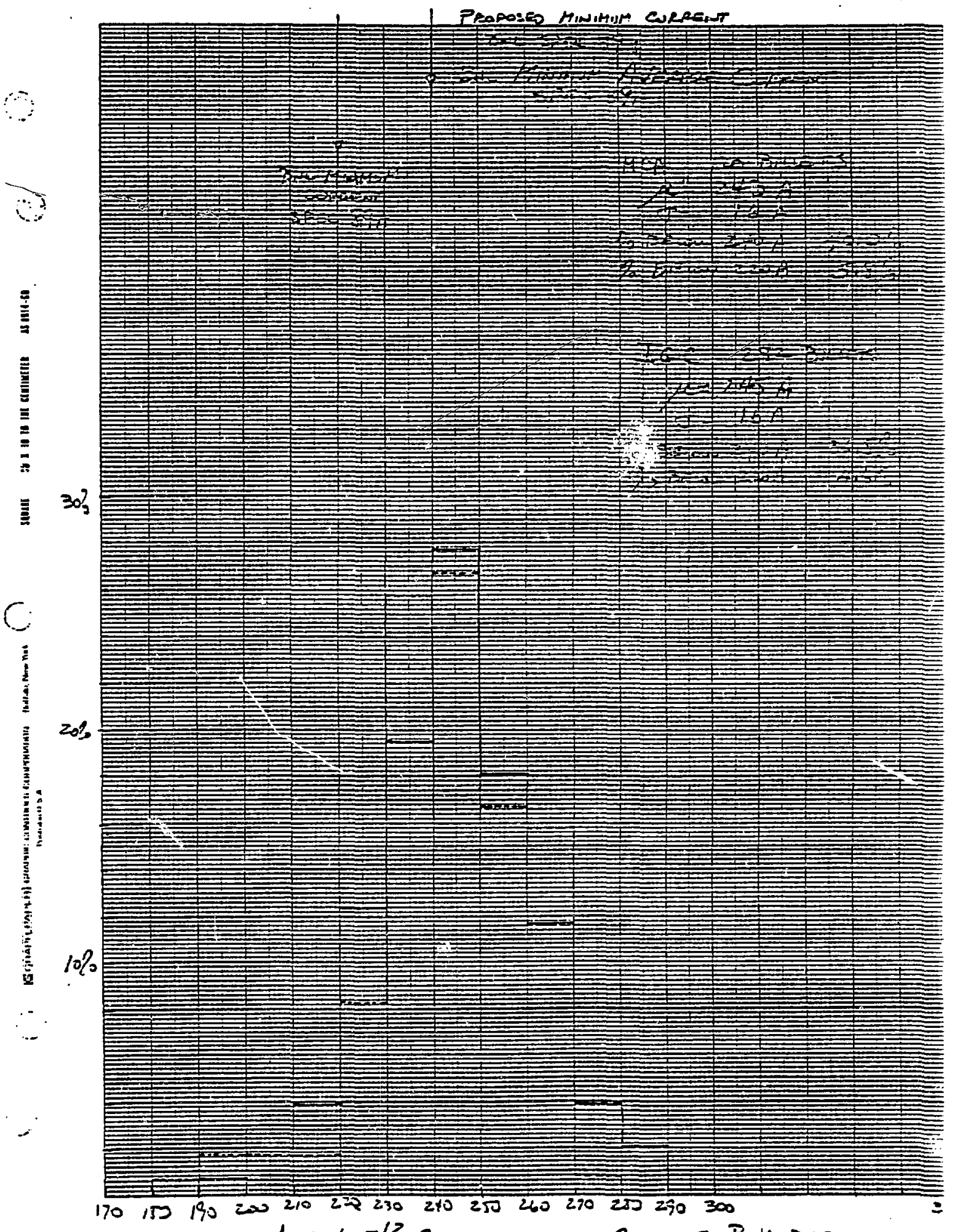




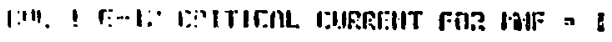

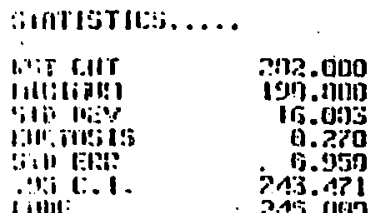

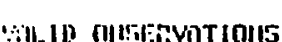

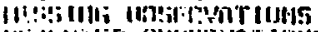

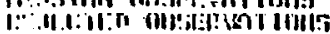

\begin{tabular}{|c|c|c|}
\hline . & 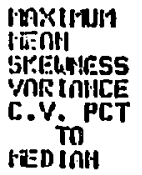 & 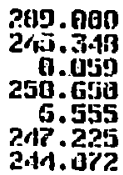 \\
\hline
\end{tabular}

\section{IIIL I E-12 CRITICAL CURREHT FOR IWF - I}

$\therefore$.

\begin{tabular}{|c|c|c|c|c|c|}
\hline $\begin{array}{l}\text { Inirop } \\
\text { Liliif }\end{array}$ & $\begin{array}{l}\text { UPPER } \\
\text { LIIIIT }\end{array}$ & $\begin{array}{l}\text { APSOLUTE } \\
\text { FREUUENCY }\end{array}$ & $\begin{array}{l}\text { RELATIVE } \\
\text { FRERUERICY } \\
\text { (PERCEHT) }\end{array}$ & $\begin{array}{l}\text { CUPULATIVE } \\
\text { REL FRI:R } \\
\text { (PERCEHT) }\end{array}$ & . \\
\hline 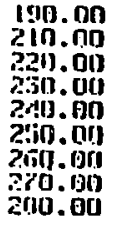 & $\begin{array}{l}200.90 \\
220.00 \\
230.90 \\
240.01 \\
250.00 \\
260.01 \\
270.90 \\
200.00 \\
290.00\end{array}$ & $\begin{array}{r}2.00 \\
11.90 \\
35.000 \\
55.000 \\
70.00 \\
51.01 \\
33.00 \\
11.00 \\
6.00\end{array}$ & $\begin{array}{r}9.71 \\
3.96 \\
12.71 \\
19.59 \\
27.613 \\
10.09 \\
11.70 \\
3.90 \\
2.13\end{array}$ & $\begin{array}{r}0.71 \\
4.61 \\
17.62 \\
36.92 \\
64.11 \\
02.27 \\
93.97 \\
97.97 \\
100.00\end{array}$ & $-\cdots$ \\
\hline & TOTnL. & 202.00 & 100.00 & 100.00 & \\
\hline
\end{tabular}




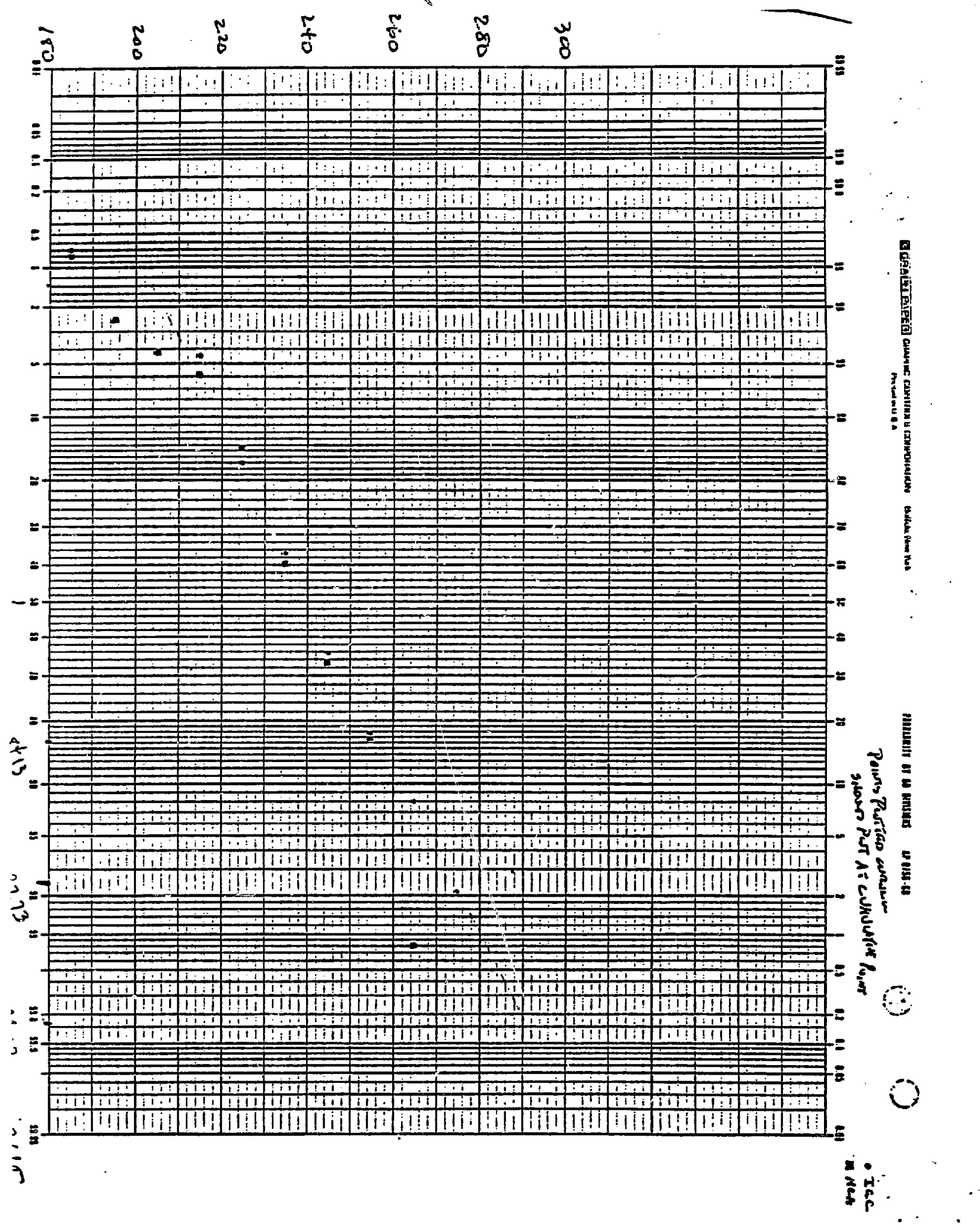


Sથ STRAHD'S CRITICAL CURREHT V. DILLET HUTBER FOR ITF - I

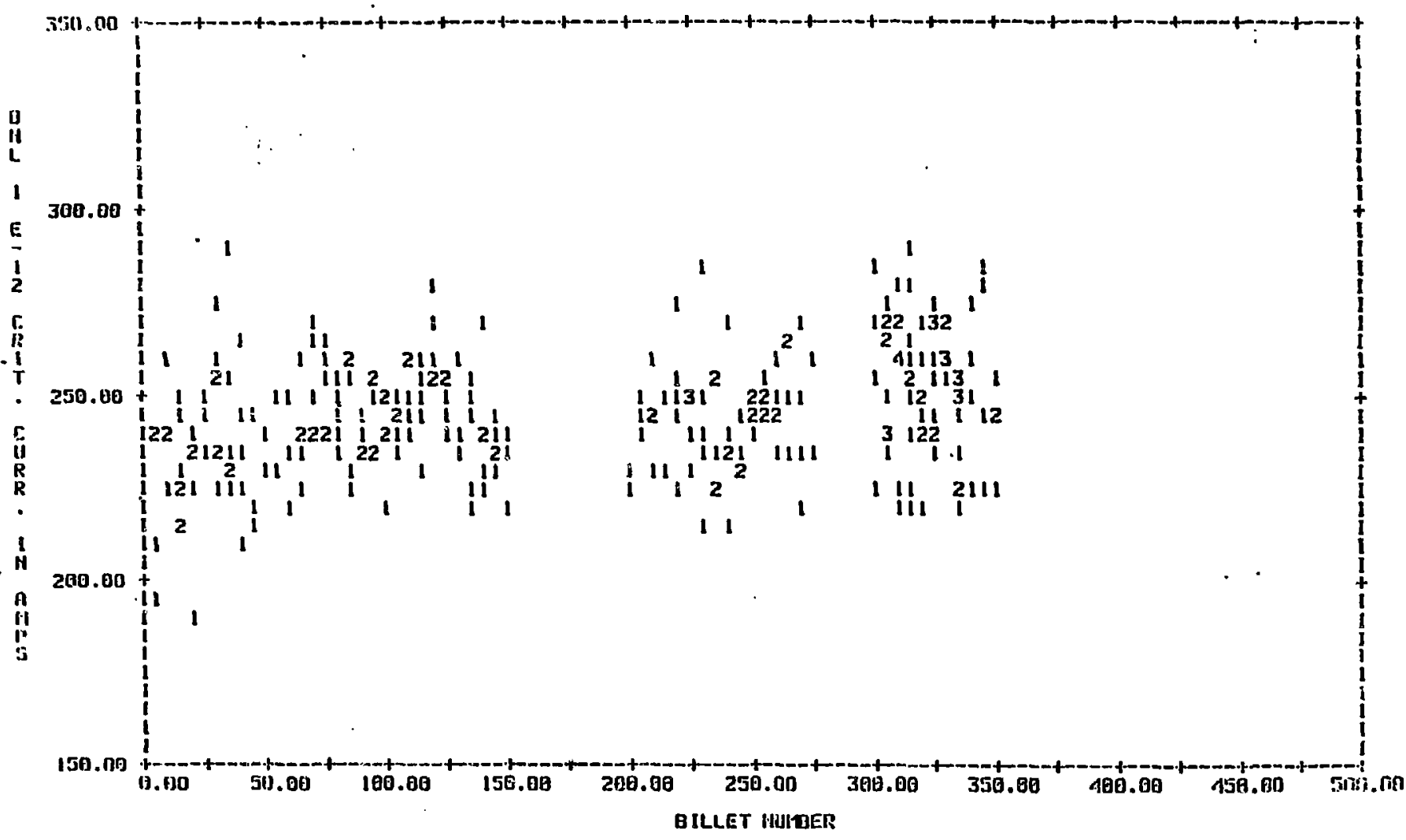


5Л STRAMD'S CRITICAL CURREMT VS. BILLET HUHDER FOR MAF - M

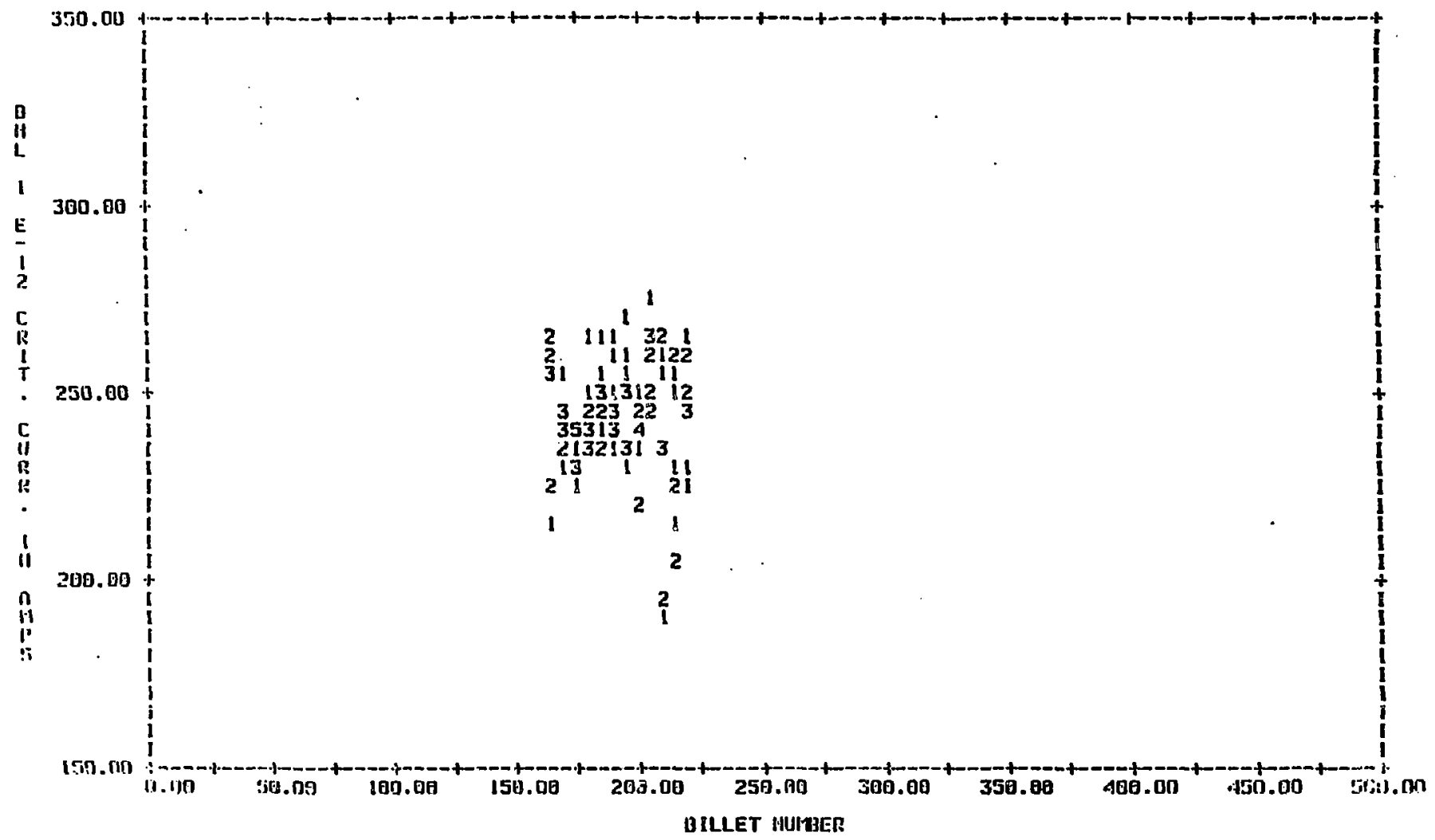




\section{$C \not \varnothing 2 \phi I N$}

ENi Reel No. Vendor Reel No. $12-3020$ Date $2 / 3 / 82$

sx: ?.0. No.

BNC-556841- 15A Vendor Onder No.

P: .307 Thickness 0525 $\mathbf{x}$ 4216

s:sard sanufacturer TGC. Insulation AlEece strand No.

$15347-10$ A I $1410^{\circ} \times 3.328-26-I$ $3 y 93 \quad$ Feet

$25-347-17-I$

$35-347-15-I 3127^{\circ} 5-328-10=5$

$45-347 \cdot 17 A-I$

$5.5-329-1-I$

$55-347-16-52859^{\prime}, 5-828-5-5$

$i s-3 Y 7-1 R^{2}-I 2050^{\prime}, 5.326-3 A-$

6, $5-328: 10-1$

S S- 3Y7- 24-I 2913' 5-328-6I

$: 05-2 n 7-21-I 3068^{\prime} \times 5 \cdot 328-8-T$

$: 15-347-80-1355^{\circ} \times 5 \cdot 128-15-5$

$12 s-347-13-5$

$13 s-347-20-I 3364^{\prime}, 5-328-10 A-I$

IL $s-347-2+I 1088^{\prime} \times 5-428-2-I$

$255-347-10-I$ 1050 $\times 5.328-10-I$

$165-547-19-I / 820^{\circ} \times 5-320-3-I$

$175-302-9-I 1103^{\prime} \times 6.328-2 A-T$

$185-547-13 A=2119^{\prime}, 5.228-9=$

$: 9 c-347-19 A-I 2410^{\circ} \times 328-4-I$ S13: $3.328-106-I$

$205-328-1 H I$

$\because 5-347-108-12972^{\prime}+5328-7-1$

$2 \pi 5-347-20 A-5$

$2=s-3 y 7-12 I 13 m^{\prime} \times s+9-2 p-I$

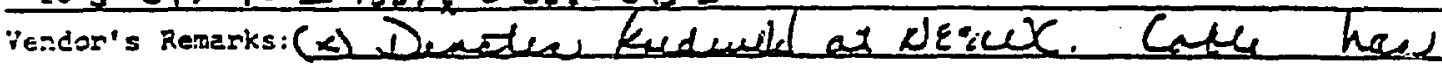
ail Eibuti lowe

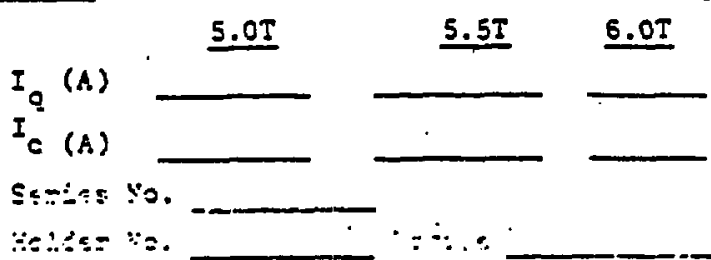




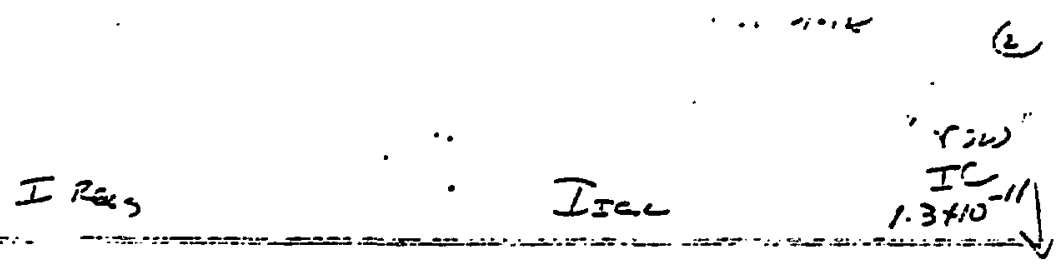

$20-1$

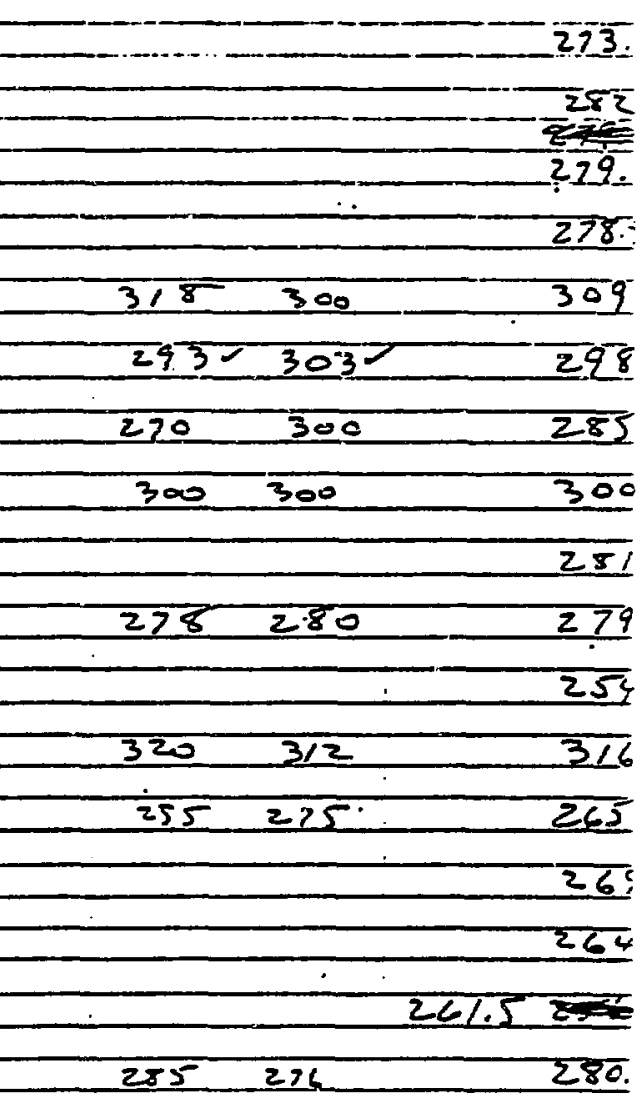

I. 2itI Z25 229

$-255$

2621

- Annsi- Ian.

$-13011$

318300

$3 / 8$

$280 \quad 303$

$293-3037$

298

3221

$300 \quad 300$

$332 I$

$288-275$

$3 \div 5-1$

$248-260$

$338 \pm$

255275

3451

$270 \quad 268$

265223

3421

$270 \quad 253$

$285 \quad 276$

255 
SHII DF 23 STRAHD CRITICAL CURREHTS IH CABLE SEGTEHTS

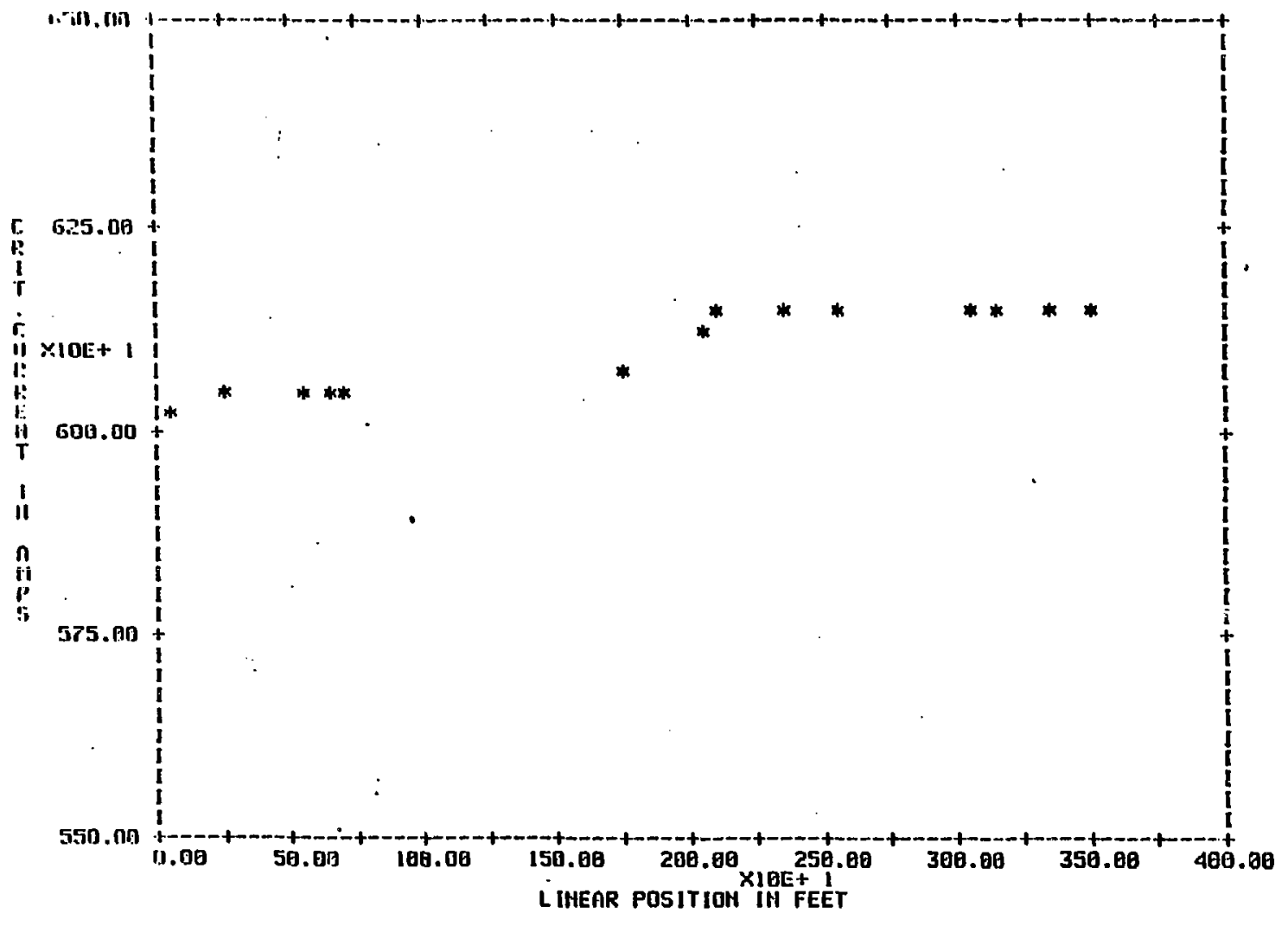


SUM OF 23 STRAHD CRITICAL CURREHTS IH CAGLE SEGMEHTS -

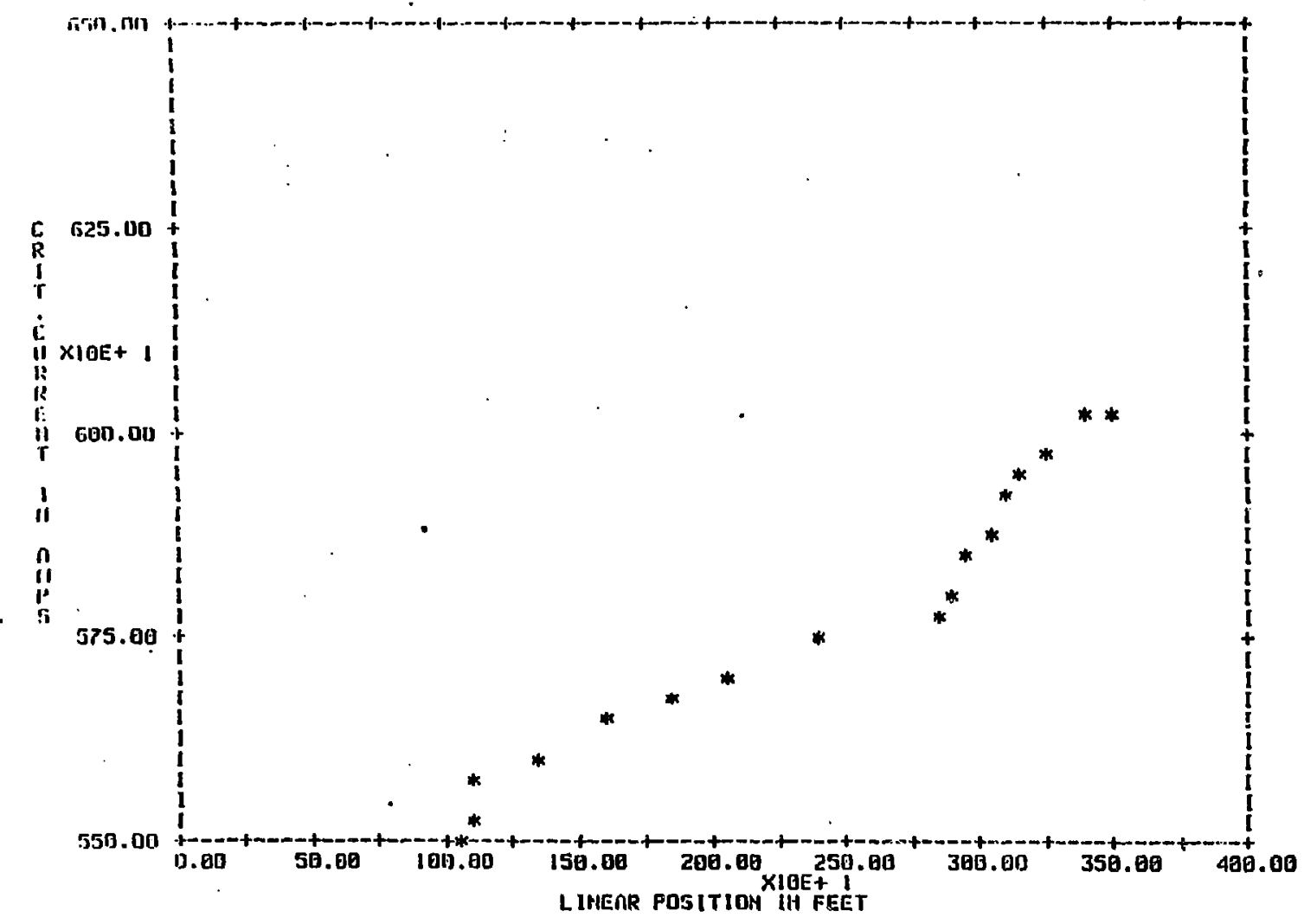

$H=0.0 \%$ 
$\begin{array}{lllll} & & \end{array}$

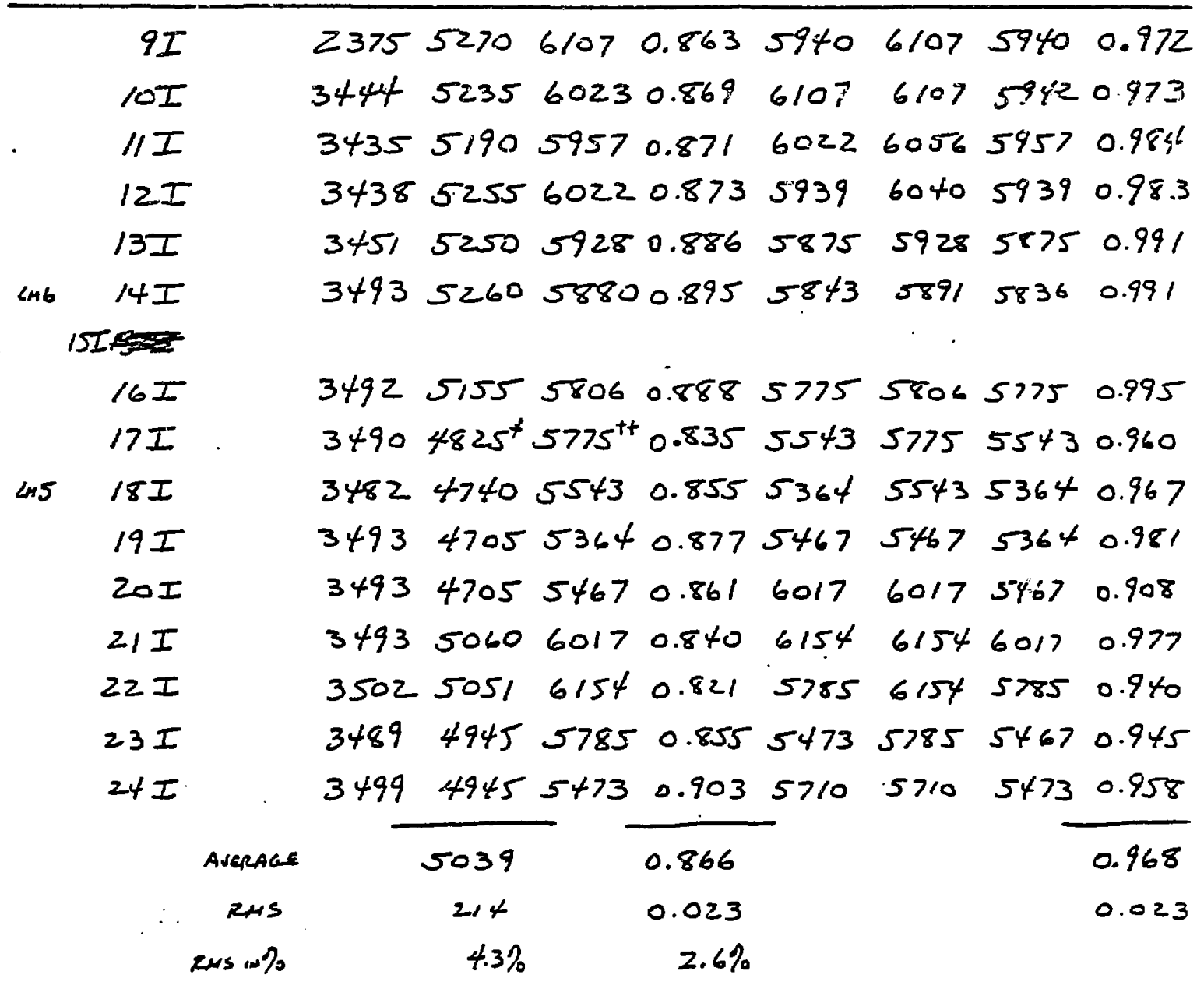




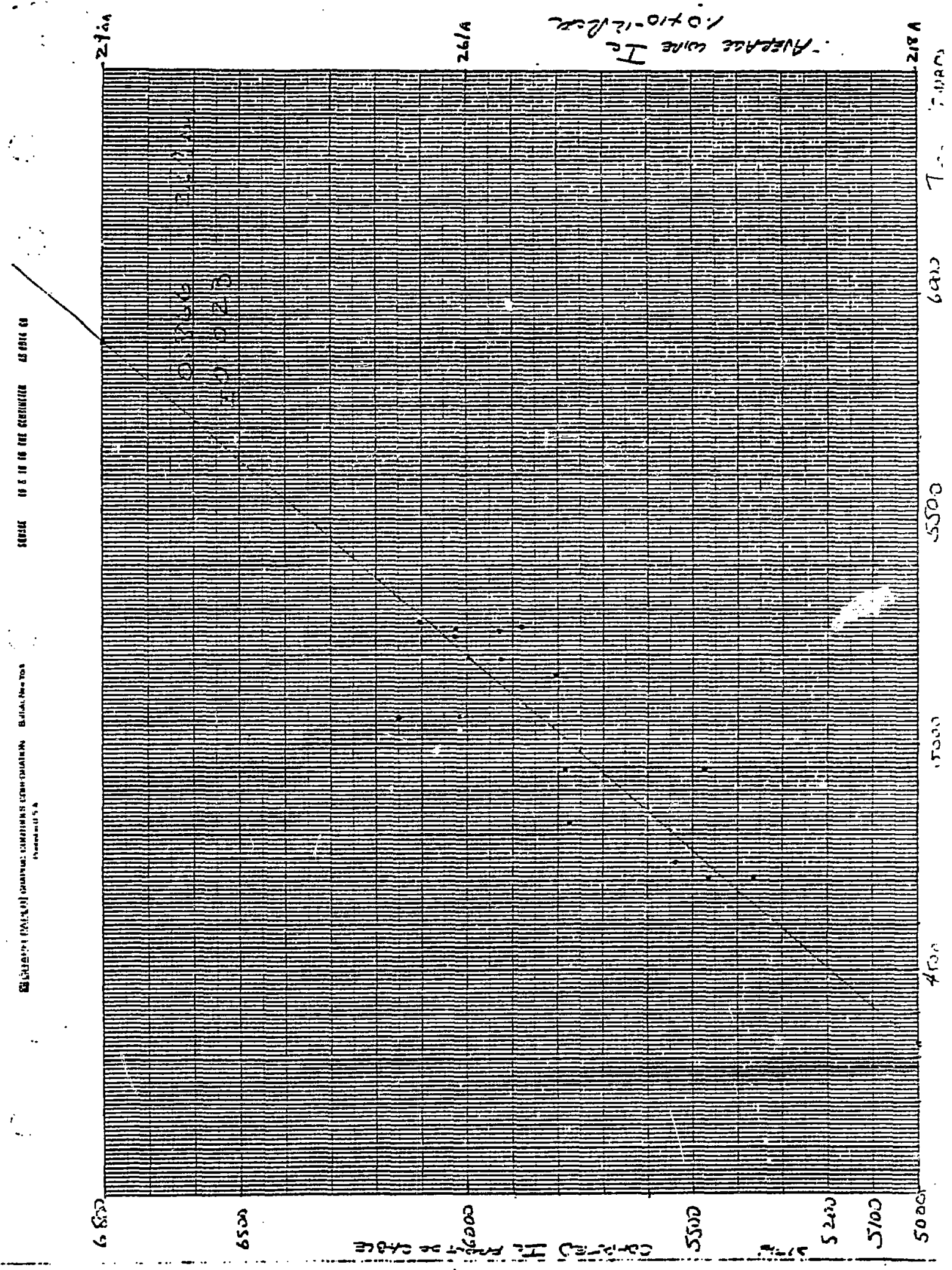




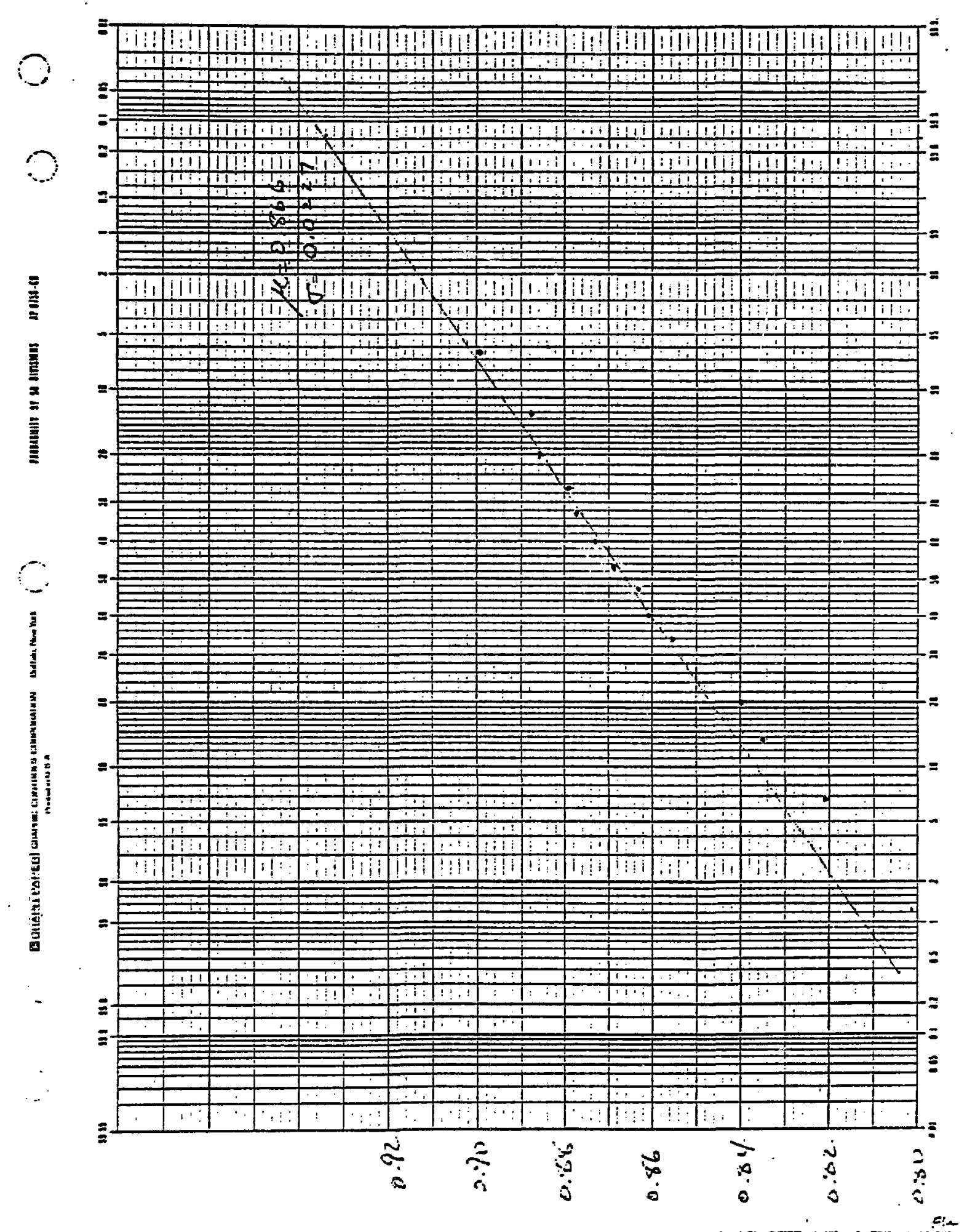


BNL Reel No.

is:

BNL P.O. No. BNL-556841-15A

Hideh .307

Thickness

Strand Manufacturer IGC

Strand No.

$15-332-21-I$

$2 S-332-17-I$ 1998, $5-247-6 A-5$

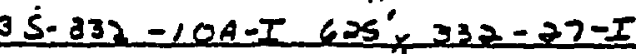

4.5.332-9-I 1552' $5347-6-I$

$55.332-86-I$ 115ix $5-347-2 A-I$

63.332 13A-I S32 $5.332-27 A-I$

$75-323=230-I 243 y^{\prime} x-547-6 B-I$

$85.332-23-I$

$95-353-20-I$

$105-332-90-I$ 3106' $\times 5.347-8 B-I$

$: 35-332-24 \div 5$ 253ix s-340-7-I 705' 5.347-8D-I

$12 S-332-2,6-I$

$135-332-100-I 179^{\prime} \times 5-332-25-I$ 257 $7^{\prime}, 347-5-A-I$

$145 \cdot 232-8=I \quad 1115^{\prime}$ s. $947-2 \cdot I$

$155-3 \pm 2-136-I$

$155-332-13-I \quad 85 i \times 5-347-1=I$

$175-332-E A-I$ 11Y3,s-347- $3-I$

$185.332-23 A-I$.

$195-332-19-I 348^{\prime} \times 5-332-26-I 2200^{\circ} \times 5-3475-I$

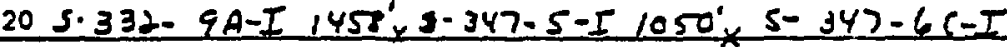

$215-332-21 A-I$

$225 \cdot 332 \cdot 1 \pm 3-I$ 136.' 5 - 347-4-I 1813'5-347-8C-I

$235 \cdot 332-238-I$

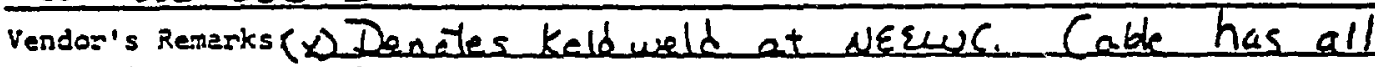

Stabrite wires:

Short Sarple Jest Data

Tested By

Dare

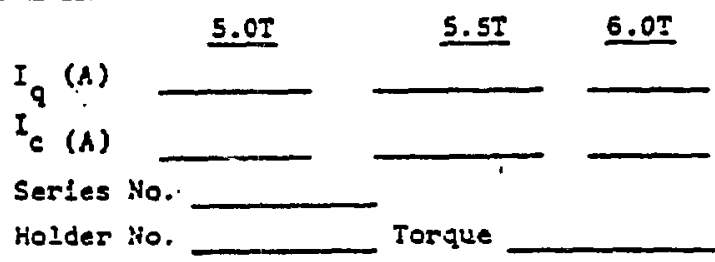




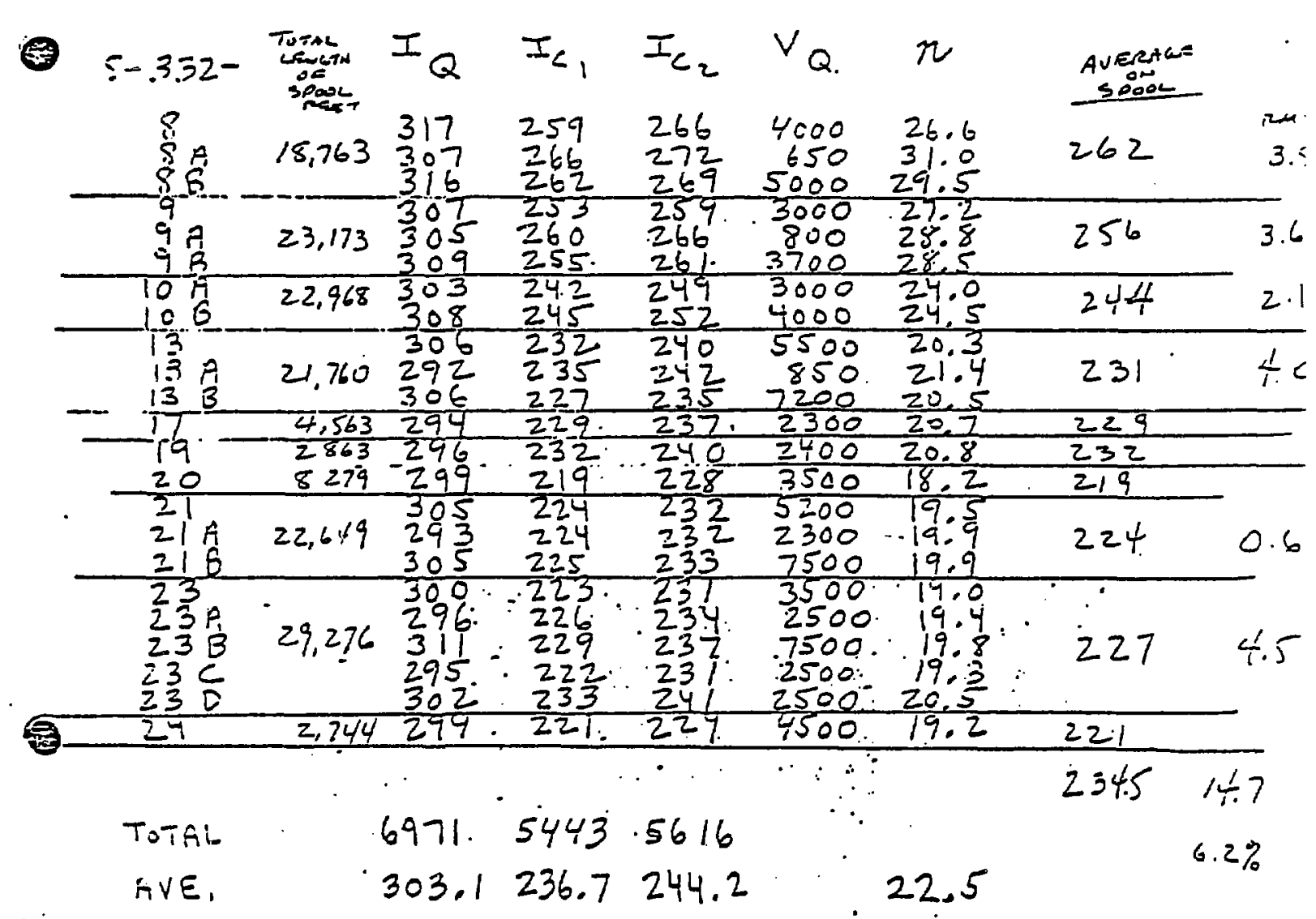

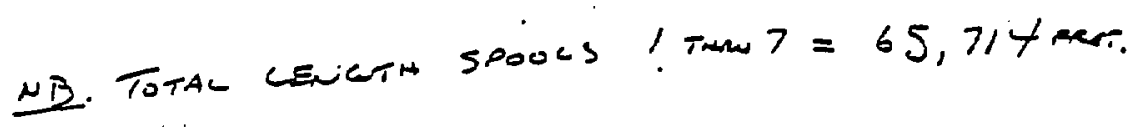




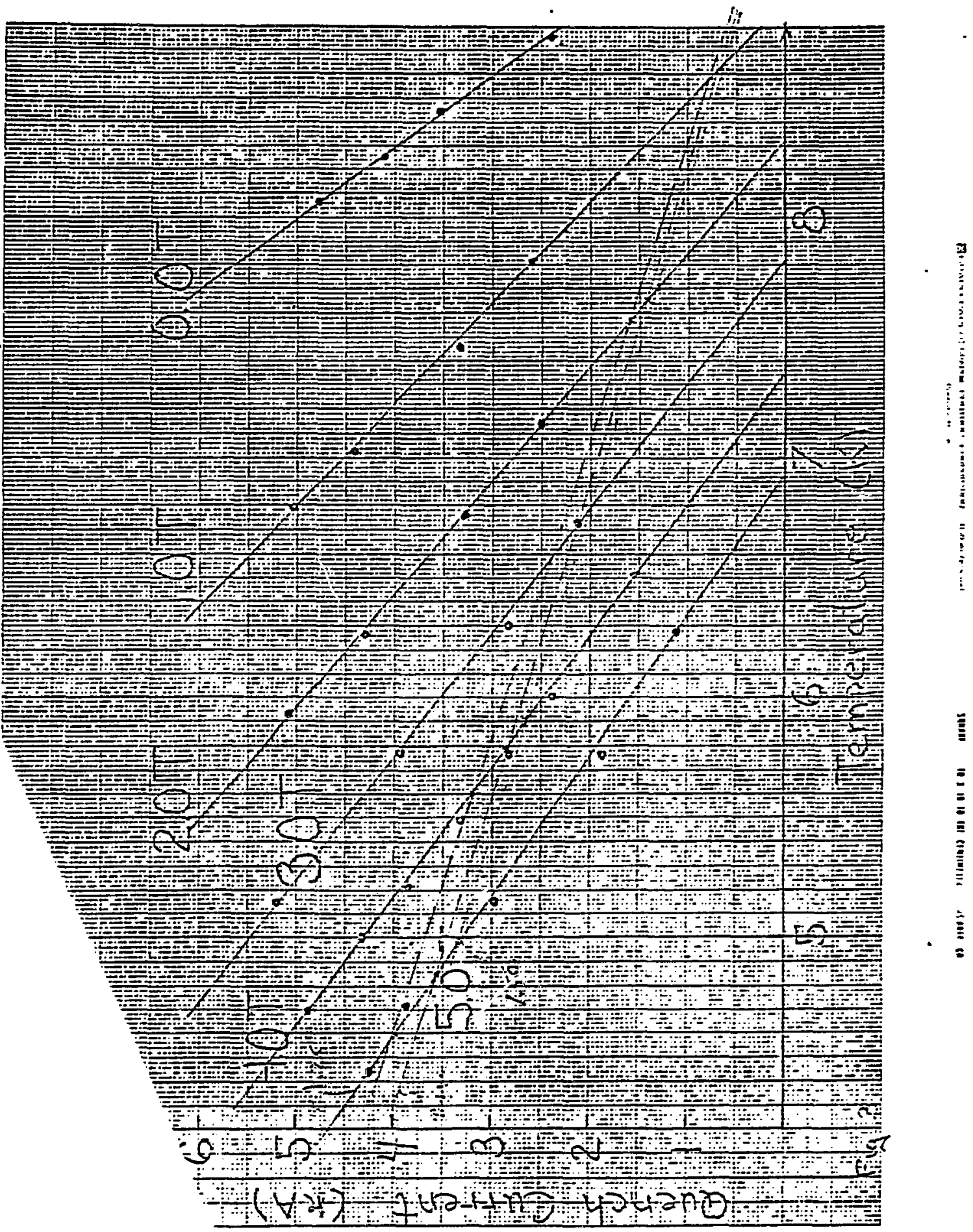




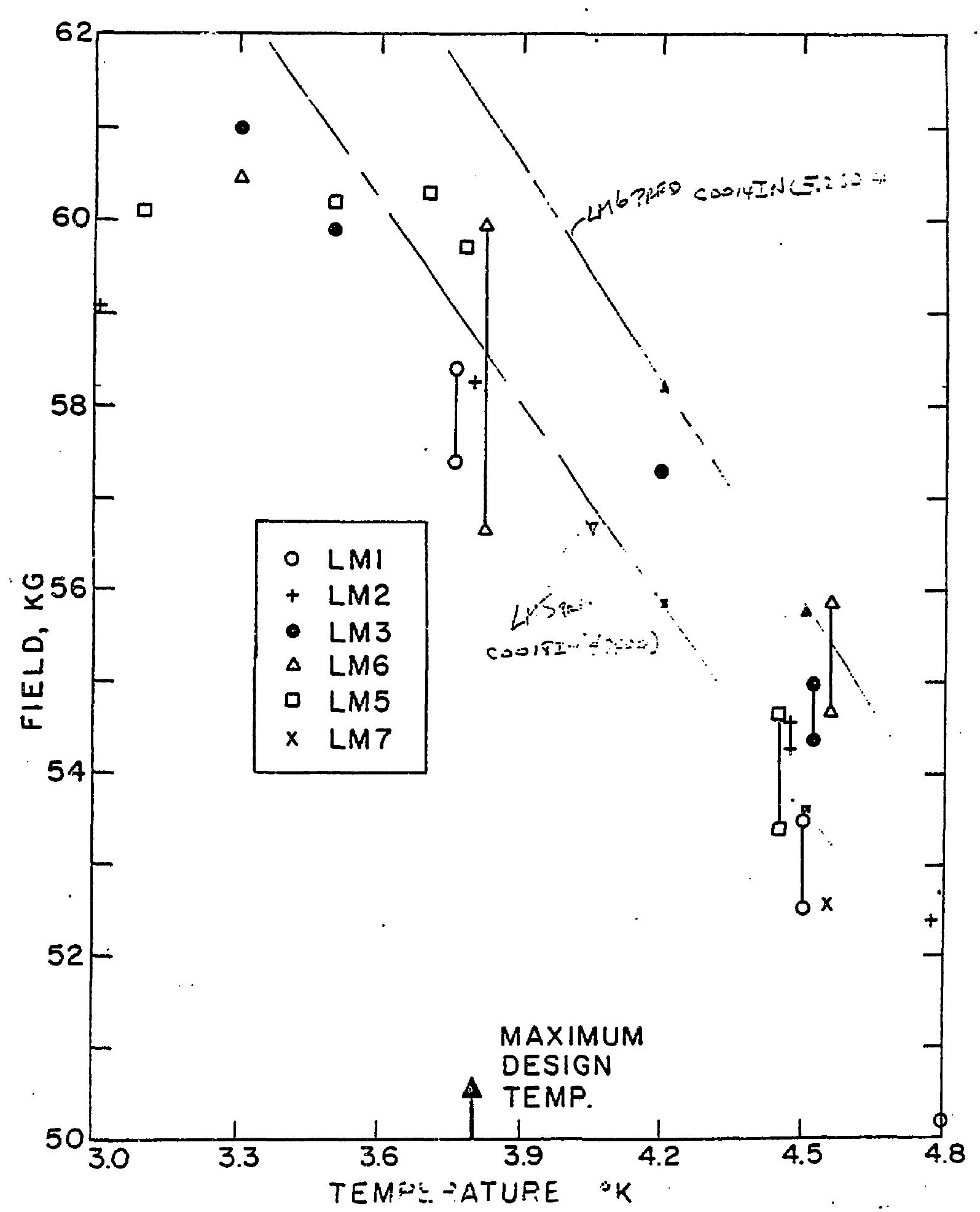

